\title{
ARVOSTELUJA
}

\section{Ilmisubjektin ja ilmisubjektittomuuden vaihtelua Lauseopin arkiston murrekorpuksessa}

MiLJA VÄÄNÄNEn: Subjektin ilmaiseminen yksikön ensimmäisessä persoonassa. Tutkimus suomen vanhoista murteista. Turun yliopiston julkaisuja, Annales Universitatis Turkuensis, sarja C, osa 430. Scripta Lingua Fennica Edita. Turun yliopisto, Turku 2016. 246 sivua +4 liitesivua.

Turun yliopistossa 9.12.2016 tarkastetussa väitöskirjassa Milja Väänänen tarkastelee ilmisubjektillisten ja ilmisubjektittomien lauseiden välistä vaihtelua suomen murteissa. Tekijä on rajannut tarkastelunsa koskemaan vain yksikön ensimmäistä persoonaa, ja tutkimus kohdistuu Isossa suomen kieliopissa määriteltyihin nominatiivimuotoisiin perussubjekteihin. Variantteina tarkastelussa ovat toisin sanoen pronominisubjekti ja nollasubjekti, ja Väänänen kertoo johdannossaan tarkastelevansa ensisijaisesti vaihtelua motivoivia lingvistisiä tekijöitä. Toissijaisesti hän tarkastelee myös alueellista variaatiota.

\section{Rakenne}

Väitöskirjansa aluksi Väänänen johdattaa lukijansa tutkimukseensa esittelemällä lyhyesti ja yleisluonteisesti tarkastelemansa ilmiön, kuvaamalla työnsä tavoitteet ja rakenteen sekä esittelemällä aineistonsa. Toinen luku on työn teoriaosaa, ja siinä tekijä tarkastelee subjektia laajasti, ensin subjektin kieliopillisia ja syntaktisia ominaisuuksia, sitten ilmisubjektittomuutta ja subjektin merkitys- ja diskurssipiirteitä ja lopuksi vielä aiempia tutkimuksia.

Väänänen tarkastelee käyttöpohjaisen kieliopin ja vuorovaikutussosiolingvistiikan teorioihin ja käsitteisiin pohjautuvasta näkökulmastaan aineistoaan. Käsittelyluvut muodostavat rakenteeltaan johdonmukaisen kokonaisuuden, jossa kvantitatiiviseen tarkastelutapaan vahvasti painottuva kolmas luku toimii perustana ja taustana muille käsittelyluvuille (4.-7.).

Kolmannen luvun tarkastelussaan Väänänen pystyy monimuuttujamenetelmin löytämään useita tarkasteltavaan ilmiöön vaikuttavia selittäviä tekijöitä. Nämä tilastollisessa kokonaistarkastelussa merkittävimmiksi osoittautuvat selittävät tekijät hän ottaa vielä tarkemmin käsiteltäviksi yksitellen omissa pääluvuissaan. Näissä luvuissa kvalitatiivinen ote painottuu, ja aineiston kvantitatiivinen tarkastelu typistyy lähinnä ristiintaulukointeihin. Neljäs luku keskittyy pronomini- ja nollasubjektien esiintymiseen eri diskursseissa ja siihen, millaiset diskurssin ilmiöt ovat olennaisia niiden ilmenemisessä. Viidennessä luvussa tekijä syventyy konjunktiolauseisiin ja kuudennessa sanajärjestykseen. Seitsemännessä luvussa vuorostaan tarkasteltavina ovat syntaktis-semanttisen verbityypin vaikutukset. Päätöslukuun Väänänen kokoaa tuloksensa ja arvioi menetelmiään ja tuloksiaan. 
Koko työn rakenne ja esimerkiksi analyysilukujen käsittelyjärjestys ovat onnistuneita. Kaiken kaikkiaan Väänänen kuljettaa lukijaa hyvin tekstissään, vaikkakin joissain yksittäisissä kohdissa lukija jää kaipaamaan vielä lisää metatekstiä ja selityksiä. Esimerkiksi kolmatta lukua seuraavien muiden analyysilukujen järjestys noudattaa aivan selvästi kolmannen luvun tilastollisessa analyysissa esitettävää selittävien muuttujien tärkeysjärjestystä, mutta tekijä ei tule kertoneeksi lukijoilleen missään, mihin tämä esitysjärjestys perustuu.

\section{Aineisto}

Väänänen tutkii aihettaan tarkastelemalla Lauseopin arkiston murrekorpuksesta rajaamaansa aineistoa. Kaiken kaikkiaan Lauseopin arkiston murreaineistossa on noin tunnin kestoiset morfologisesti ja syntaktisesti annotoidut näytteet 132 pitäjänmurteesta, jotka edustavat kattavasti kaikkia suomen murteita. Näistä Väänänen on valinnut aineistokseen 43 pitäjänmurteen näytteet, jotka edustavat seitsemää päämurrealuetta: lounaismurteita, hämäläismurteita, Etelä-Pohjanmaan murretta, keski- ja pohjoispohjalaisia murteita, peräpohjalaismurteita, savolaismurteita ja kaakkoismurteita. Tekijä on pyrkinyt valikoimaan kultakin murrealueelta näytteet samasta alamurreryhmästä: Lounaismurteiden näytteitä on valittu vain pohjoisryhmästä, hämäläismurteita perihämäläisistä murteista, keski- ja pohjoispohjalaisia murteita vain pohjoispohjalaisista, peräpohjalaisia murteita pääosin Kemin murteista, savolaismurteita pohjoissavolaisista murteista ja kaakkoismurteita varsinaisista kaakkoismurteista sekä Lappeenrannan seudun välimurteista muttei esimerkiksi Inkerin suomalaismurteista.

Kuten tunnettua Lauseopin arkiston murreaineistossa lähtökohtaisesti kunkin paikkakunnan murretta edustaa vain yksi näyte, jossa äänessä on vain yksi, tyypillisesti 180o-luvun lopulla syntynyt, informantti. Kuva kustakin murteesta syntyy myös Väänäsen väitöskirjassa siis yhden idiolektin perusteella, toisaalta arkiston murreaineisto on alueellisesti poikkeuksellisen - suorastaan ainutlaatuisen - edustava. Väänäsen tutkimukseen Lauseopin arkiston aineisto soveltuu kaiken kaikkiaan hyvin. Laaja korpus mahdollistaa sen, että hän pystyy poikkeuksellisen laajasti tarkastelemaan ilmiötä sekä kvantitatiivisesti että kvalitatiivisesti. Väitöskirjassa on tarkasteltavana kaikkiaan 5513 lausetta, jossa predikaattiverbi on yksikön ensimmäisessä persoonassa.

Väänäsen työtä voi pitää korpuslingvistisenäkin, vaikkei hän sellaiseksi sitä luonnehdikaan. Hän on ensinnäkin hyödyntänyt tarjolla ollutta valmiiksi koostettua ja järjestettyä aineistokokonaisuutta. Annotoituun korpukseen on ollut helpompi tarttua kuin itse kerättyyn aineistoon, joka olisi pitänyt kenttätyön lisäksi myös itse litteroida ja luokitella syntaktisesti ja morfologisesti. Juuri tämän kaltaisten tutkimusten mahdollistamiseksi Lauseopin arkisto on aikanaan koostettukin, ja Väänäsenkin työ on erinomainen esimerkki siitä, kuinka aiemmin suppeammista aineistosta tarkasteltuja ilmiöitä voidaan tarkastella korpuslingvistisesti yhä suuremmista aineistoista. Erikseen on korostettava sitäkin, ettei kukaan voi väittää, että Väänänen olisi istunut valmiiksi katettuun pöytään ja että hän tuntisi valitsemansa ja rajaamansa aineiston vain ulkokohtaisesti. Päinvastoin yhtenä hänen ansioistaan täytyy pitää sitä, että hän on koostanut murrekorpuksesta saamansa aineiston pohjalta oman aineistotietokannan, jonka tarkka koodaaminen ja muodostaminen ovat olleet perusedellytyksiä esimerkiksi sille, että Väänänen pystyy tarkastelemaan aihettaan monimuuttujamenetelmin.

Väänäsen tietokanta muodostuu 5513 esiintymästä konteksteineen, ja kustakin esiintymästä hän on koodannut seuraavista selittävistä muuttujista esiintymäkohtaiset tiedot: murrealue, pitäjittäinen murre, konjunktio, verbityyppi, esikenttä, referentiaalinen etäisyys, aikamuoto ja 
polaarisuus. Konjunktioalkuiset lauseet Väänänen on merkinnyt tietokantaan sen konjunktion mukaan, jolla lause alkaa. Verbityypin hän on luokitellut Anneli Pajusen (2001) verbityyppiluokituksen pohjalta ja sitä soveltaen. Voidakseen tarkastella sanajärjestyksen mahdollisia vaikutuksia vaihteluun on Väänänen kirjannut kustakin esiintymästä kenttäjakoa koskevan tiedon. Perussubjekti sijoittuu neutraalissa järjestyksessä teemapaikalle, mutta tätä voi edeltää esikenttä. Tietokannassa on otettu huomioon nimenomaan tämä esikenttä, ja teemapaikkaa edeltävistä lausekkeista tutkija on ottanut huomioon predikatiivin tai objektin, adverbiaalin ja partikkelin. Esiintymäkohtaisesti hän on kirjannut tiedon myös referentiaalisesta etäisyydestä diskurssissa tarkoitteen maininnan ja edellisen maninnan välillä. Etäisyys on ilmaistu välissä olevien lauseiden määränä. Polaarisuustietoihin tekijä on merkinnyt tiedon siitä, onko kyseessä kielto- vai myöntölause.

Aineiston esittelyn yhteydessä Väänäsellä on nimitysten käytössä paikoitellen terävöitettävää. Esimerkiksi sivun 15 taulukossa hän kutsuu päämurrealueita murrealueiksi ja murrealueiden hän esittää koostuvan paikkakunnista. Edellisestä poiketen sivun 40 taulukossa päämurrealueet ovatkin hänen mukaansa murteita ja yksittäiset paikkakunnan murteet tai pitäjittäiset murteet ovat pitäjiä tai puhujia. Koska tarkasteltavana on kieli, tarkasteltavina eivät liene paikkakunnat tai pitäjät vaan niiden murteet, ja ennen kaikkea tärkeää olisi, että tekijä olisi käyttänyt nimityksiä yhdenmukaisesti koko monografiassa. Kun Väänänen viittaa murteella välillä murrealueeseen ja välillä paikallismurteeseen, on lukijan on oltava tarkkana ja pääteltävä, kumpaa hän oikeastaan tarkoittaa.

\section{Teoreettinen tausta ja aiempi tutkimus}

Subjektia käsittelevä toinen luku on tiivis ja informatiivinen. Väänänen tarkastelee suomen kielen subjektin kieliopillisia ja syntaktisia ominaisuuksia käsittelemällä sekä fennististä että kansainvälistä tutkimusta. Hän käsittelee subjektin syntaktisia ja kieliopillisia ominaisuuksia, tarkastelee nollasubjektia kielitypologisesta näkökulmasta kriittisesti ja perustelee nollasubjektin käyttöä keskeisenä käsitteenään sekä käy läpi tiiviisti subjektin semanttisia piirteitä ja diskurssiominaisuuksia. Toisen luvun päättävässä alaluvussa hän vielä esittelee ilmiötä aiemmin käsitelleitä tutkimuksia ja sitä, miten hän itse asemoi tutkimuksensa aiempaan tutkimukseen nähden.

Väänänen käyttää lähteitä järkevästi aiheensa taustoituksena ja valintojensa perusteluina. Esimerkiksi Isosta suomen kieliopista poiketen Väänänen ei liitä nollasubjektia vain nollapersoonaan, vaan hän käyttää käsitettä myös puheaktipersoonan ilmisubjektittomuudesta. Ratkaisulleen hän saa tukea kansainvälisistä tutkimuksista, joissa on tutkittu subjektin ilmaisutavan vaihtelua. Samassa yhteydessä hän kuitenkin korostaa, ettei hän ajattele yksikön ensimmäisen persoonan subjektipronominittomien lauseiden olevan samassa mielessä subjektittomia kuin aidosti subjektittomat lauseet kuten tilalauseet, joissa ei argumenttirakenteessa ei ole ihmisviitteistä ykkösargumenttia. Hän käsittelee myös kieliopillisen ja kognitiivisen subjektin suhdetta ja avaa lukijoille kieliopillisen subjektin yhtymäkohtia topiikkiin ja teemaan.

\section{Kohteena subjektin ilmaisemisen vaihtelu}

Analyysinsä Väänänen aloittaa tarkastelemalla aineistoaan tilastollisesti monimuuttujamenetelmin. Tarkasteltavien muuttujien keskinäisiä suhteita hän tarkastelee ensin satunnaismetsämenetelmällä ja sitten logistisella regressiolla. Lopuksi kirjoittaja selvittää vielä pitäjittäisten 
murteiden (puhujien) välisiä eroja ja yhtäläisyyksiä soveltamalla päätöspuuanalyysiä.

Tilastolliset menetelmät on valittu tarkoituksenmukaisesti ja perustellusti. Ilmisubjektin ja ilmisubjektittomuuden vaihtelua on tutkittu ennen Väänästäkin, ja tutkimuksissa on esitetty yksittäisiä ilmiöön vaikuttavia tekijöitä. Äärimmäisen harvinaiseksi Väänäsen väitöskirjan tekee kuitenkin se, että tätä vaihteluilmiötä tarkataan tilastollisesti ottamalla yhtäaikaisesti useita selittäviä tekijöitä huomioon. Eri monimuuttujamenetelmien soveltamisen ansiosta välittyy ilmiöstä täydempi kuva kuin vain eri selittäviä tekijöitä yksitellen erikseen tarkastelemalla tai vain soveltamalla jotakin yhtä monimuuttujamenetelmää.

Analyysin perusteella vahvimmin vaihteluun vaikuttaa referentiaalinen etäisyys edelliseen mainintaan nähden. Variaation vaikuttavat tärkeysjärjestyksessä myös lauseita mahdollisesti yhdistävä konjunktio, lauseen alun esikenttä, murreryhmä ja syntaktis-semanttinen verbityyppi. Näitä selittäviä tekijöitä Väänänen tarkastelee erikseen vielä erillisissä pääluvuissaan. Sen sijaan polaarisuutta ja aikamuotoa, jotka hän on sisällyttänyt monimuuttuja-analyysiin ja jotka vaikuttavat analyysin perusteella vähiten vaihteluun, Väänänen ei enää käsittele kolmannen luvun jälkeen erikseen.

Monimuuttujamenetelmiä sovellettuaan Väänänen siirtyy tarkastelemaan selittäviä tekijöitä yksitellen, ja hän varaa kunkin tekijän käsittelyyn oman pääluvun (luvut 4.-7.). Vaikka näissäkin luvuissa aineistoa tarkastellaan kvantitatiivisesti - lähinnä ristiintaulukoinnein -, on pääpaino aineiston kvalitatiivisessa analyysissä. Työhön on sisällytetty runsaasti esimerkkejä, joita kirjoittaja malttaa avata lukijoilleen kiitettävästi.

Väänänen analysoi ensin subjektin tarkoitteen diskurssiasemaa, joka on hänen tulostensa mukaan keskeisin tarkasteltuun vaihteluun vaikuttava tekijä. Tässä luvussa Väänänen tarkastelee sekä referentiaalista etäisyyttä että toistovaikutusta, ja henkilökohtaisesti pidän tätä ja sanajärjestystä käsittelevää kuudetta lukua työn kiinnostavimpina osioina.

Referentiaalisuus ja nollasubjektin esiintyminen kytkeytyvät työssä tiiviisti toisiinsa. Nollasubjektillisista esiintymistä 80 prosentissa referentiaalinen etäisyys on vain yksi tai kaksi lausetta: saman referentin edellinen samaviitteinen maininta on siis välittömästi edeltävässä lauseessa tai sitä edeltäneessä. Samaan selittävään tekijään on kiinnitetty aiemmassakin tutkimuksessa huomiota, ja referentiaalisuudella on havaittu olevan yhteys subjektin poisjättämiseen suomen lisäksi myös virossa. Kvalitatiivisen tarkastelunsa pohjalta Väänänen päättelee, että ilmisubjektittomissa tapauksissa etäisyys on pieni, koska nollasubjektit ovat usein sidoksissa kontekstuaalisesti johonkin juuri edellä esitettyyn. Edellä esitettyä esimerkiksi täydennetään, tarkennetaan tai korjataan, ja tyypillisiä täsmentämiseen liittyviä rakenteita ovat esimerkiksi itsekorjaukset, parenteesit ja limittäisrakenteet.

Väänänen laajentaa subjektin diskurssiaseman tarkastelua vielä tutkimalla, millaisia vaikutuksia kahdella lähekkäin esiintyvällä samaviitteisellä subjektilla on toisiinsa, eli tarkastelemalla toistovaikutusta. Hänen analyysissaan toistovaikutuskin osoittautuu tilastollisesti merkitseväksi, mutta hän näkee sen tarkastelussa myös ongelmia: ennen muuta vaikeaa on erottaa mahdollinen toistovaikutus muista nollasubjektin vaikuttavista tekijöistä.

Viidennessä luvussa tarkasteltavaksi otetaan konjunktiot ja tarkemmin se, millaisissa merkityssuhteissa erilaiset konjunktiolauseet ovat ympäröivään kontekstiinsa nähden ja millaisia tehtäviä niillä voi olla puhutussa vuorovaikutuksessa. Koska kyse on puhutusta kielestä, Väänänen ottaa järkevästi huomioon, että konjunktiot eivät puheessa vain yhdistä lauseita toisiinsa tai ole vain lausumanalkuisia, vaan että ainakin osa konjunktioista esiintyy myös lausuman tai vuoron loppuasemissa. 
Kaiken kaikkiaan konjunktiota käsittelevä osuus on kirjoitettu sujuvasti. Väänänen kytkee aineistoanalyysinsä hyvin aiempaan kansainväliseen ja kotimaiseen tutkimuksen ja tarjoilee lukijoilleen laajasta aineistosta kiinnostavia havaintoja ja tuloksia. Tästäkään luvusta ei ole suurta huomautettavaa, vaan lähinnä siihen olisi kaivannut satunnaisesti pieniä lisämainintoja tai selityksiä. Esimerkiksi konjunktioluvussa käsitellessään ja-konjunktiota Väänänen referoi muun muassa Chafen (1988) tutkimusta ja pohtii, missä suhteessa subjektin ilmaiseminen on puheen yksiköihin ja niitä jaksottaviin ja-konjunktioihin. Hänen pohdintansa ovat kiinnostavaa luettavaa, mutta eduksi olisi ollut tässä yhteydessä, jos siinä olisi mainittu edes lyhyesti suomalaista foneettista tutkimusta, joka käsittelee nimenomaan prosodista jaksottelua ja esimerkiksi intonaatiojaksoja (esim. Aho 2010; Yli-Luukko 2010). Kun-lausetta ja sen tehtäviä tarkastellessaan Väänänen toteaa, että murteiden kun-lauseen tehtävänä on täsmentää edeltävän lauseen tapahtumahetkeä, mutta temporaalisuuden merkityksen lisäksi sillä voi olla myös kausaalinen ja kontrastiivinen merkitys (s. 135). Viimeksi mainituista hän antaa aineistostaan esimerkkejä ja kytkee tämän hyvin osaksi subjektin ilmaisemisen vaihtelua. Tässä yhteydessä olisi voinut tuoda vielä selvemmin esiin, että Lauseopin arkiston murreaineiston litteraateissa esiintyvät $k u(n)$, $k o(n)$ ja $k o ̈(n)$ ovat hyvin yleiskäyttöisiä ja että ne voivat vastata muun muassa kirjoitetun yleiskielen kun-, kuin- ja koska-konjunktiota tai vaikkapa relatiivista konjunktiota. Juuri edellä mainitusta syystä on erittäin laajaan arkiston murrekorpukseen merkitty osaan edellä mainituista tapauksista jäänyt virheellisesti hakusanaksi kun. Tämä mahdollinen ongelma koskenee vain pientä osaa esiintymistä, mutta lukija jää miettimään, missä määrin tekijä on huomannut tämän seikan. Esimerkiksi sivulla 136 Väänänen esittää esimerkin, jossa konjunktiolla on sekä minusta että Väänäsestä perusteleva merkitys. Nähdäkseni sillä ei ole kuitenkaan perustelevaa merkitystä temporaalisen merkityksen lisäksi, vaan kyseisessä esimerkissä esiintyvän ko-konjunktion hakusana lienee todellisuudessa $k o s k a$, eli tulkintani mukaan esimerkin konjunktiolla ei ole temporaalista merkitystä ollenkaan. Puutteet tai monitulkintaisuudet ovat kuitenkin pieniä työn ansioihin verrattuna.

Sanajärjestyksen vaikutusta subjektin ilmaisemiseen väitöskirjassa tarkastellaan kuudennessa luvussa. Tarkkaan ottaen Väänänen analysoi lauseen alun järjestystä ja sitä, mitkä mahdolliset kieliopilliset ainekset edeltävät finiittiverbiä ja mahdollista subjektipronominia. Tarkastelussaan hän hyödyntää Ison suomen kieliopin kenttäkuvausta ja erityisesti esikentän käsitettä. Lausekkeiden järjestyksen lisäksi hän ottaa huomioon myös lauseiden informaatiorakenteen. Käsittelyssään hän esittää hyvin, että aitoa kielenkäyttöä tutkittaessa on syytä ottaa huomioon vaikutteita kummastakin tarkastelutavasta.

Väänänen analysoi, että nollasubjektillisissa lauseissa esikentässä esiintyy tilastollisesti merkitsevän usein adverbiaali tai objekti. Ilmisubjektilliset lauseet taas ovat ilmisubjektittomia lauseita useammin sanajärjestykseltään neutraaleja, eli ne alkavat subjektina toimivalla pronominilla tai esimerkiksi konnektiivilla. Vahvimmin esikenttäalkuiset lauseet myötävaikuttavat nollasubjektin esiintymiseen savolaismurteissa ja pohjoispohjalaisissa murteissa. Diskurssinäkökulmasta tarkasteltuina objektilla ja adverbiaalilla alkavilla nollasubjektillisilla lauseilla hahmottuu kaksi selväpiirteistä funktiota, jotka ovat emfaattisuus ja kontrastiivisuus.

Seitsemännessä luvussa Väänänen tarkastelee verbin syntaktis-semanttisen tyypin vaikutusta subjektin ilmaisemisen vaihteluun. Verbityyppiluokittelunsa pohjana hän käyttää Pajusen (2001) kuvausta. Väänänen pohjustaa analyysiään esittelemällä ensin Pajusen luokituksen ja sen perään oman Pajusen mallin perusteella muokkaamansa luokituksen. Tämäkin osio on pääpiirteissään kirjoitettu sujuvasti, mutta Pajusen luokituksen, oman luokituksensa ja näiden 
kahdenväliset erot olisi voinut sanallisen kuvauksen lisäksi esittää vielä havainnollisemmin esimerkiksi asetelmalla.

Analyysissään Väänänen osoittaa, että kognitio-, puhe- ja tilaverbit myötävaikuttavat pronominisubjektin esiintymiseen, kun taas liikeverbit ja transitiiviset muutosverbit tukevat nollasubjektia. Savolaismurteet erottuvat verbityyppien tarkastelussa kuten monessa muussakin käsittelyluvussa: niissä suositaan nollasubjektia, kun kyse on liikeverbeistä, tilaverbeistä tai kognitioverbeistä. Kvalitatiivisessa tarkastelussaan Väänänen nostaa esiin muun muassa, että minä sanoin -ilmausta käytetään kiteytyneenä diskurssirakenteena, jolla merkitään puheen jakso referoiduksi. Tällä ilmauksella on joitain fraasimaisuutta ilmentäviä piirteitä, joita ovat ilmisubjektin säännöllinen esiintyminen, esiintyminen ilman että-komplementoijaa ja äänteellinen redusoituminen. Muihin verbityyppeihin ei Väänäsen havaintojen mukaan näyttäisi liittyvän erityisiä diskurssirakenteita ilmi- tai nollasubjektillisina.

\section{Kokoavaa arviointia}

Milja Väänänen on rakentanut väitöskirjaansa aiemmissa tutkimuksissa esitettyjen havaintojen pohjalta hyvän tutkimusasetelman, jossa hän onnistuu syventämään ennen esitettyjä tutkimustuloksia ja löytämään selityksiä subjektin ilmaisutapojen variaatiolle diskurssissa. Väitöskirjan tekijä on perehtynyt hyvin aiheeseensa ja siihen liittyvään tutkimukseen, ja hän taustoittaa tutkimiaan ilmiöitä hyvin. Väänänen suhtautuu aiempaan tutkimukseen kypsän kriittisesti. Tarkastelussaan hän yhdistää tarkoituksenmukaisesti kvantitatiivista ja kvalitatiivista analyysiä ja hyödyntää käsittelyssään laajaa korpusaineistoa. Työn ansioihin nähden ovat työn puutteet vähäisiä. Väänäsen hyvä tutkimus rohkaisee toivottavasti muitakin tulevia väittelijöitä tarttumaan laajoihin puhutun kielen korpuksiin.

TOMMI KURKI

tommi.kurki@utu.fi suomen kieli ja suomalais-ugrilainen kielentutkimus 20014 Turun yliopisto

\section{Lähteet}

Ано, EIJA 2010: Spontaanin puheen prosodinen jaksottelu. Väitöskirja. Helsingin yliopisto, Nykykielten laitos, yleinen kielitiede.

Chafe, Wallace 1988: Linking intonation units in spoken English. J. Haiman ja S. A. Thompson (toim.): Clause combining in grammar and discourse, 27-55. John Benjamins, Amsterdam-Philadelphia.

Pajunen, Anneli 2001: Argumenttirakenne. Asiaintilojen luokitus ja verbien käyttäytyminen suomen kielessä. Suomi 187. Suomalaisen Kirjallisuuden Seura, Helsinki.

Yli-LuUkKo, Eeva 2010: Hämäläisten laulu - puheen melodinen jaksottaminen. Virittäjä, 396-409. 